\title{
PERLINDUNGAN HUKUM TERHADAP KONSUMEN ATAS IKLAN YANG MELANGGAR TATA CARA PERIKLANAN
}

\author{
Khotbatul Laila \\ Fakultas Hukum Universitas Merdeka Malang \\ J. Terusan Dieng No. 62-64; Malang; 65146; Indonesia; (0341) 580161 \\ ella.khotbatul.laila@gmail.com
}

\begin{abstract}
The process of the birth of an ad is a very important process for a product marketing of a company because advertising is the lifeblood of a company. Advertising process is a very important step to determine the success of a company for its products. There are advertising rules agreed by several parties to create ads. The rule is called the advertising code of ethics which states that advertising must be honest, responsible and not contrary to applicable law is very relevant to the articles contained in the Consumer Protection Act. Therefore, the importance of avoiding fraud done by the producers, it is necessary to include information related to the product in order to protect the interests of consumers. In Indonesia, there are no laws that specifically regulate the advertising, making the rules about advertising is still subject to some rules of law. Consumers have a lot of confusion when going to claim compensation related violations of violations in the advertising world because it is still a blurring the person in charge of the violation.
\end{abstract}

Keywords: Advertising, Consumer, Legal Protection.

\begin{abstract}
Abstrak
Proses lahirnya sebuah iklan adalah proses yang sangat penting bagi sebuah pemasaran produk dari sebuah perusahaan karena iklan merupakan darah kehidupan bagi suatu perusahaan. Proses periklanan merupakan tahapan yang sangat penting untuk menentukan keberhasilan suatu perusahaan atas produknya. Terdapat aturan periklanan yang disepakati oleh beberpa pihak dalam membuat iklan. Peraturan tersebut dinamakan kode etik periklanan yang menyatakan bahwa iklan harus jujur, bertanggung jawab, dan tidak bertentangan dengan hukum yang berlaku sangat relevan dengan pasal-pasal yang terdapat dalam Undang-Undang Perlindungan Konsumen. Oleh karena itu pentingnya untuk menghindari kecurangan yang dilakukan oleh produsen maka perlu mencantumkan informasi terkait produk tersebut guna melindungi kepentingan konsumen.Di Indonesia belum adanya undang-undang yang mengatur secara khusus tentang periklanan, menjadikan peraturan tentang periklanan masih tunduk pada beberapa aturan perundang-undangan. Konsumen banyak mengalami kebingungan ketika akan melakukan tuntuan ganti rugi terkait pelanggaran pelanggaran di dunia periklanan dikarenakan masih kaburnya penanggung jawab dari pelanggaran tersebut.
\end{abstract}

Kata kunci:Perlindungan Hukum, Periklanan, Konsumen. 


\section{Perlindungan Hukum terhadap Konsumen Atas Iklan yang Melanggar Tata Cara Periklanan}

Khotbatul Laila

Arus globalisasi dan arus perdagangan bebas telah menunjukkan kekuatannya dalam bidang ekonomi dan mengharuskan pelaku usaha untuk berkompetisi dalam meraup keuntungan yang sebesarbesarnya, dan salah satu alat yang digunakan untuk memasarkan produk guna meraup keuntungan yang besar dengan menggunakan iklan atau promosi. Dampak perekonomian global telah merekonstruksi pola pikir dan kultur masyarakat untuk selalu ikut serta dalam lalu lintas perdagangan barang dan jasa baik wilayah nasional atau internasional, khususnya masyarakat di negara-negara berkembang yang mempunyai kecenderungan masyarakat dengan budaya konsumtif.

Kecenderungan masyarakat konsumtif ini dijadikan lahan basah bagi pengusaha untuk mengeksploitasi minat beli masyarakat dengan membuat iklan atas produk barang atau jasa dengan iklan yang sangat menggiurkan konsumen. Tataran ekonomi khususnya pada aspek marketing, iklan menempati posisi yang sangat penting karena setiap perusahaan akan mengalokasikan dana khusus yang tidak sedikit untuk keperluan periklanan. Mobilitas periklananyang tinggi dengan segala atribut dan instrument pendukung yang begitu sensasional dan tidak jarang menembus batas rasionalitas serta daya tarik psikologis menjadi sasaran utama sebagian besar pelaku usaha periklanan untuk mendongkrak target penjualan yang lebih tinggi sehingga keuntungan perusahaan akan semakin besar.

Setiap pelaku usaha meyakini bahwa iklan memberikan sumbangsih besar terhadap pemasaran produk pasca produksi sehingga besarnya anggaran untuk promosi merupakan konsekuensi logis dalam persaingan bisnis yang bukan tidak mungkin menimbulkan resiko terhadap pelaku usaha tersebut atau terhadap konsumen yang menggunakan produk tersebut.

Iklan diatur dengan beberapa klausula yang terdapat dalam Pasal 8 Undang-Undang Republik Indonesia Nomor 8 Tahun 1999 tentang Perlin- dungan Konsumen (UU PK), yang menyatakan dalam salah satu ayatnya bahwa pelaku usaha dilarang memproduksi dan atau memperdagangkan barang dan atau jasa yang tidak sesuai dengan kondisi, jaminan, keistimewaan, atau kemanjuran sebagaimana dinyatakan dalam label, etiket, atau keterangan barang dan atau jasa tersebut.

\section{Perkembangan Periklanan}

Seiring dengan perkembangan teknologi yang semakin membaik, biro-biro iklan juga bersaing untuk menyediakan fungsi-fungsi kreatifnya seperti pembuatan iklan yang menarik dan membujuk konsumen untuk membeli produk yang sedang diiklankan. Dengan demikian kedudukan biro-biro iklan kemudian berubah menjadi agenagen pelayanan yang bersifat multifungsi dan independen.

Menurut kalangan ekonom, definisi standar periklanan mengandung 5 elemen (Simatupang, 2004):

1. Periklanan adalah bentuk komunikasi yang dibayar walaupun beberapa bentuk periklanan seperti iklan layanan msyarakat menggunakan ruang khusus yang tidak berbayar dengan alokasi waktu dan kesempatan yang relative sedikit.

2. Didalam proses pembuatan iklan terjadi pula proses identifikasi sponsor, iklan tidak hanya menampilkan pesan mengenai kehebatan produk yang ditawarkan melainkan juga menyampaikan pesan supaya konsumen mengetahui produsen dariproduk tersebutsehingga

3. Maksud yang terkandung dari semua iklan yang dibuat adalah untuk membujuk atau mempengaruhi konsumen untuk melakukan suatu kegiatan yang dirancang sedemikian rupa sampai dapat mempengaruhi konsumen untuk menggunakan produk tersebut.

4. Periklanan memerlukan elemen media penyampai pesan untuk menyampaikan pesan kepada msyarakat sebagai sasaran.

5. Penggunaan media massa ini menjadikan periklanan dikategorikan sebagai komunikasi massal sehingga periklanan mempunyai sifat nonpersonal. 
6. Perancangan iklan harus jelas ditentukan kelompok konsumen yang akan menjadi sasaran pesar, tanpa identifikasi audiens yang jelas, pesan yang disampaikan dalam iklan tidak akan efektif.

Produksi iklan, perusahaan periklanan dikawal oleh UUPK serta kode etik periklanan. Kode etik periklanan terdapat banyak aturan yang ditetapkan untuk melindungi hak-hak konsumen dan mencegah pelanggaran yang dilakukan oleh produsen atau pelaku usaha bidang periklanan. Diantara aturan dalam kode etik periklanan menyatakan bahwa iklan harus jujur, bertanggung jawab dan tidak bertentangan dengan hukum yang berlaku (asas umum tata krama dan tata cara periklanan Indonesia), hal tersebut sangat relevan jika disandingkan dengan perlindungan konsumen yang mengatur beberapa pasal tentang periklanan yang menyatakan, " promosi adalah kegiatan pengenalan atau penyebarluasan informasi suatu barang dan atau juga untuk menarik minat beli konsumen terhadap barang dan atau jasa yang akan dan sedang diperdagangkan".

Secara khusus beberapa perbuatan yang dilarang bagi pelaku usaha periklanan diatur dalam UU PKPasal 17 Ayat 1 yaitu pelaku usaha periklanan dilarang memproduksi iklan yang:

1. Mengelabuhi konsumen mengenai kualitas, kuantitas, bahan, kegunaan dan harga barang dan atau tarif jasa serta ketetapan waktu penerimaan barang dan atau jasa.

2. Memuat informasi yang keliru, salah, atau tidak tepat mengenai barang dan atau jasa.

3. Tidak memuat informasi mengenai resiko pemakain barang dan atau jasa.

4. Mengeksploitasi kejadian dan atau seseorang tanpa persetujuan bersangkutan.

5. Melanggar etikaatau ketentuan peraturan perundangundangan.

Beberapa ketentuan larangan tentang periklanan, terdapat beberapa hal yang harus diper- hatikan pelaku usaha dalam tata cara periklanan, yaitu: (Simatupang, 2004,)

1. Definisi iklan yang diindentikkan dengan kata promosi yaitu sebagai suatu kegiatan pengenalan dan penyebarluasan informasi untuk menarik minat beli konsumen, secara de facto pemahaman terhadap definisi iklan tersebut seringkali ditafsirkan pelaku usaha bahwa iklan merupakan semacam alat, dengan menghalalkan muatan informasi apa saja, sematamata untuk menggugah minat beli masyarakat sehingga seringkali iklan yang dibuat merugikan konsumen.

2. Hak konsumen untuk mengakses informasi dari penayangan iklan telah diatur secara tegas bahwa konsumen harus mendapatkan informasi yang yang benar, jelas dan jujur mengenai kondisi dan jaminan barang dan atau jasa. Ketiga muatan informasi (jelas, benar, jujur) wajib diberikan kepada konsumen sebagai pengguna produk barang atau jasa.

3. Terdapat kewajiban pelaku usaha sebagai timbal balik dari hak konsumen yang harus dipenuhi oleh pelaku usaha tetapi seringkali terjadi pelaku usaha tidak memberikan informasi apapun tentang kondisi yang sebenarnya dari produk barang.

Batasan periklanan yang terdapat didalam kode etik periklanan atau didalam UU PK telah menyebutkan secara jelas, akan tetapi secara penerapan peraturan di wilayah Indonesia kurang medapat tanggapan secara serius dari pihak pelaku usaha sebagai pemilik produk yang gencar dalam memberikan informasi, hal tersebut dikarenakan batas kreatifitas manusia kadangkala tidak bisa terbendung dan diukur sampai menembus batas rasionalitas.

Karakteristik utama pengawasan hukum melalui penetapan berbagai peraturan terkait kode etik periklanan tercermin dari:

1. Bahwa pasal hukum tertulis menyatakan secara tegas bahwa pemasangan iklan harus tunduk dan mengutamakan kepentingan masyarakat dengan sanksi denda atau kurungan jika terbukti bersalah melalaui pelanggaran. 
2. Peraturan diharapkan dapat mengungkap halhal illegal yang semula tersembunyi.

3. Makna dari sebagian pasal dari undangundang sangat bergantung pada interpretasi pengadilan dan baru efektif sampai timbul kasus yang benar-benar sudah sangat merugikan konsumen.

Menurut Felicia Lidya Rampen (2013), di Indonesia belum adanya undang-undang yang mengatur secara khusus tentang periklanan tentang periklanantunduk pada beberapa perundang-undangan seperti Undang-Undang perlindungan konsumen, Undang-Undang Kesehatan, Undang-Undang tentang Penyiaran dan Peraturan pemerintah lainnya. Mengingat banyaknya ketentuan undang-undang terkait dengan kegiatan periklanan, tidak jarang mengalami hambatan dalam menentukan kepeda siapa beban tanggung jawab harus diarahkan ketika konsumen dirugikan baik secara materiil maupun non materiil oleh informasi yang kurang tepat yang terdapat pada suatu iklan (Rampen, 2013).

Klasifikasi beban tanggung jawab secara hukum pada cacat produk tentu akan merujuk pada UU PK. begitu pula jika menyangkut beban tanggung jawab media informasi yang relatif banyak peraturan yang mengaturnya. Tetapi jika persoalan yang ada adalah tentang kreatifitas iklan yang dilakukan oleh biro-biro iklan, maka ukuran yang diperbolehkan dan yang tidak diperbolehkan menjadi sulit diketahui batasannya. Selain mengacu pada UU PK, periklanan juga mengacu pada ketentuan Undang-Undang Republik Indonesia Nomor 23 Tahun 1992 tentang Kesehatan dan Badan Pengawas Obat dan Makanan (BPOM). Direktorat Jendral POM dalam melakukan pengawasannya sampai hari ini masih mendasarkan diri pada ordonansi pemeriksaan farmasi (Staatblad 1936 Nomor 660), akan tetapi ordonansi tersebut tidak secara khusus mengatur masalah periklanan sehingga ordonansi tersebut memerlukan penja- baran lebih lanjut dalam peraturan perundangundangan lainnya.

Pemakaian tenaga profesional seperti dokter, perawat, ahli farmasi, rumah sakit atau atribut profesi medis lain sebagai model iklan dilarang oleh kode etik periklanan. Sebagian kecil rumusan kode etik, telah tampak banyak iklan obat yang tidak memenuhi persyaratan, yang akan merugikan konsumen sebagai pengguna dari produk.

Sebagian besar konsumen Indonesia masih sangat rentan dalam menyerap informasi iklan yang tidak sehat, oleh karena itu sangat riskan jika wilayah periklanan tidak diadakan pengawasan yang memadai dan konsumen dibiarkan menimbang-nimbang serta memutuskan sendiri iklan yang bertanggung jawab. Posisi yang tidak seimbang antara produsen (lebih menguasai) dan konsumen (mudah dikuasai) akan mudah disalahgunakan (machtpositie) oleh produsen yang berjalan didukung oleh fasilitas yang memungkinkan untuk bertindak monopolistic.

Undang-Undang Republik Indonesia Nomor 7 Tahun 1996 tentang Pangan juga disebutkan secara jelas mengenai iklan pangan yaitu dalam Pasal 33, "setiap label dan atau iklan tentang panagn yang diperdagangkan harus memuat keterangan mengenai pangan secraa benar dan tidk menyesatkan ", oleh karena itu pemerintah mengatur, mengawasi dan melakukan tindakan yang dperlukan supaya iklan tentang pangan yang diperdagangkan tidak memuat keterangan yang menyesatkan.

\section{Pelanggaran Tata Cara Periklanan secara Umum}

Pentingnya informasi tentang mutu atau kualitas dan segala hal yang terkait dengan produk barang atau jasa yang ditawarkan juga diharapkan dapat memproteksi konsumen dari praktek-praktek iklan yang mengandung unsur kecurangan dan penipuan (deception) (Umboh, 2014).

Iklan yang mengandung unsur penyesatan dan penipuan: 
1. Iklan pancingan (Bait and switch ad)

Iklan yang sebenarnya tidak berniat untuk menjual produk yang ditawarkn tetapi lebih ditujukan untuk menarik minat konsumen dengan tawaran discount harga atau hadiah menarik. Di amerika iklan pancingan demikian dikategorikan sebagai iklan pancingan yang memberikan informasi yang menyesatkan.

2. Iklan menyesatkan

Iklan yang selalu mngesankan "keampuhan" suatu barang dengan cara mendemonstrasikannya dengan cara berlebihan dan menjurus kearah penyesatan. Media yang digunakan pada umunya adalah televisi Karen tayangan dilayar kaca dapat dibuat lebih mengesankan dan tampak lebih bagus (Nasution, 1995).

Di Indonesia iklan-iklan yang cenderung menyesatkan bahkan mengandung unsur penipuan banyak sekali dapat dijumpai baik melalui media cetak maupun media elektronik diantara:

a. Iklan tentang perumahan yang menyatakan jarak antara perumahan dengan pusat kota "hanya 15 menit saja" tetapi iklan tersebut tanpa keterangan lebih pasti tentang bagaimana jarak tersebut ditempuh, menggunakan alat transportasi sehingga dapat menempuh jarak tersebut. Padahal ukuran waktu 15 menit apakah untuk mereka yang berjalan kakai, naik sepeda motor, naik mobil atau lewat jalan tol. Salah satunya tentu saja benar menurut seorang yang memakai kendaraan pribadi dan melalui jalan tol tetapai sebaliknya apaakah bagi seorang yang berjalan kaki atau menggunakan sepeda motor waktu yang ditemouh akan sama seperti yang menggunakan mobil pribadi sedangkan calon pengguna perumahan tersebut tidak mungin semua menggunakan kendaraan pribadi.

b. Iklan produk kecantikan yang umumnya menonjolkan atau mengeksploitasi hal-hal yang bersifat menjanjikan kebaikan dan keberhasilan pemakaian produk kecantikan akan tetapi disisi lain iklan tidak menginformasikan akibat-akibat buruk atau efek samping yang dapat merugikan konsumen. c. Iklan obat yang tidak menyebutkan "baca aturan pakai" sehingga tidak ada peringatan dari produsen untuk membaca terlebih dahulu bagaimana baik dan buruk obat tersebut.

Prakteknya iklan-iklan yang tidak jujur dan tidak bertanggung jawab masih tetap berjalan dan resiko atau efek buruk dari produk tersebut akan dipikul oleh konsumen sebagai pemakai produk. Banyak aspek yang mempengaruhi sulitnya penegakan hukum dalam praktek periklanan baik dari kalangan konsumen, pelaku usaha maupun belum adanya political will dari pemerintah.

Secara garis besar iklan dapat digolongkan menjadi 7 kategori yaitu (Leder \& Shears, 1996) iklan konsumen, iklan bisnis, iklan perdagangan, iklan eceran, iklan keuangan, iklan langsung, iklan lowongan kerja. Beberapa jenis iklan tersebut diatas, iklan yang banyak terkait dengan perlindungan konsumen yang banyak terdapat pelanggaran adalah iklan konsumen (consumer advertising), dengan melihat perspektif hukum dalam rangka memberikan perlindungan bagi konsumen dari iklan yang menyesatkan (deception) dan yang mengandung unsur penipuan (Simatupang, 1999).

Consumer advertising terdapat dua macam barang yang umum dibeli masyarakat yaitu barang konsumen(consumer goods)seperti bahan makanan, bahan-bahan konfeksi, alat-alat pembersih. Dunia periklanan semua barang dianggap lazim disebut sebagai Fast Moving Consumen Goods (FMCGs) yakni barang-barang konsumen yang perputarannya cukup cepat. Seperti halya obat-obatan yang dikemas dan diberi merek dan diecerkan yang biasa disebut over the counter (OTC) yang merupakan obat-obat merk dagang untuk membedakan obatobat resep yang dijual diapotik berdasarkan resep dokter.

Selain Consumer Goods juga terdapat barang tahan lama (durable goods), barang jenis ini ditawarka oleh produsen dengan harga yang lebih mahal seperti mobil, rumah tinggal, perhiasan, 


\section{Perlindungan Hukum terhadap Konsumen Atas Iklan yang Melanggar Tata Cara Periklanan}

Khotbatul Laila

barang-barang elektronik. Terdapat beberapa kategori iklan yang telah melanggar tata cara (kode etik) periklanan dan melanggar aturan perundangundnag berdasarkan data yang telah dicatat oleh Badan Pengawas Periklanan Indonesia (BPPI) baik dalam media cetak maupun medaia eletronik. Pelanggaran kode etik periklanan dalam penerapan umum tentang:

a. Penggunaan kata-kata yang berlebihan seperti menggunakan kata-kata "ter ", "Paling", "nomor satu" dan sejenisnya tanpa menjelaskan efeek samping dari produk tersebut.

b. Adanya "perbandingan langsung", iklan yang baik tidak akan membandingnya produknya secara langsung dengan produk-produk pesaingnya. Apabila perbandingan ini diperlukan, maka dasar perbandingan harus sama dan jelaa secara esensi sehingga konsumen tidak disesatkan dengan perbandingan tersebut.

c. Iklan yang "merendahkan produk lain" dan "peniruan" tidak boleh beredar dikalangan masyarakat. Peniruan meliputi merek, logo, komposisis huruf dan gambar, slogan, positioning, cara penampilan dan jingle.

d. Iklan tidak diperbolehkan menampilkan anakanak dalam adegan yang berbahaya, menyesatkan atau tidak pantas dilakukan oleh anakanak.

e. Iklan tidak diperbolehkan dengan menampilkan atau menggunakan Tenaga professional seperti Dokter, ahli farmasi, tenaga medis, atau atribut profesi lain yang digunakan untuk proses pemyampaian iklan kepada konsumen.

Beberapa kriteria iklan yang dilarang pengoperasiannya diIndonesia terdapat pada UU PK dalam Pasal 8, Pasal 9, Pasal 10, Pasal 11, Pasal 12, Pasal 13, Pasal 14, Pasal 15, Pasal 16, Pasal 17. Kriteria iklan yang dilarang oleh Tata Krama dana Tata Cara (Kode Etik) periklanan Indonesia yang telah disempurnakan dirumuskan dalam Bab I dan Bab
II. Kriteria iklan yang dilarang ini dimaksudkan agar tujuan dan fungsi periklanan terhadap konsumen dapat berjalan lancar dan saling menguntungkan kedua belah pihak (produsen dan konsumen).

Faktor-faktor yang melatarbelakangi danay pelanggaran Kode Etik Periklanan pada umumnya adalah:

a. Pada dasarnya para pengusahamenginginkan keuntungan sebesar-besarnya dalam memasarkan produknya sehingga hal apapun akan dilakukan untuk mendapatkan keuntungan tersebut, tidak terkecuali memberikan informasi yang berlebihan kepada konsumen.

b. Ketidakpahaman makna yang tersurat didalam tata cara (kode etik) serta peraturan yang mengatur periklanan.

c. Dalam mengakses informasi tentang suatu produk, konsumen membutuhkan suatu kejelasan atau cara untuk memeilih lebih teliti dalam mengkonsumsi suatu produk barang atau jasa. Hal tersebut hingga saat ini yang belum didapatkan oleh konsumen sehingga hal itu dimanfaatkan oleh produsen untuk mengeksploitasi daya beli masyarakat terhadap suatu barang.

d. Adanya persaingan antara pelaku usaha dengan pelaku usaha lainnya. Hal tersebut dikarenakan jika salah satu pengusaha melakukan pelanggaran dan tidak mendapatkan sanksi yang tegas maka pengusaha lain akan melakukan hal yang sama karena tidak ada sanksi yang tegas yang diterapkan.

\section{Perlindungan Hukum Bagi Konsumen Atas Iklan yang Melanggar kode Etik periklanan}

Secara hukum terdapat banyak definisi tentang periklanan baik definisi menurut UndangUndang atau peraturan maupun definisi yang dikemukananoleh para ahli. Tams Djayakusumah (1997) menyatakan periklanan adalah salah satu bentuk spesialisasi publistik yang bertujuan untuk 
mempertemukan satu pihak yang menawarkan sesuatu dengan pihak lain yang membutuhkan.

Suatu periklanan, pada dasarnya konsumen pengguna tidakakan mengetahui semua jenis barang tanpa adanya informasi yang berbentuk iklan sehingga masyarakat sebagai konsumen pengguna sangat memerlukan informasi tersebut tentang produk secara detail tentang kondisi baik dan buruknya sebuah produk.

Menurut Howard Beales, terdapat 4 hal yang harus diatur berkenaan dengan pentingnya informasi bagi konsumen yang mengikat secara hukum bagi pelaku usaha yang terlibat dalam produksi suatu iklan, diantaranya adalah (Simatupang, 2004): (a)Consumer information the law, informasi bagi konsumen yang dilindungi oleh hukum adalah sekaligus merupakan kewajiban bagi produsen. Informasi penting yang harus dikemukakan oleh produsen adalh menyangkut tentang harga, kualitas dan mutu, efek samping dan semua hal yang perlu diketahui oleh konsumen sebagai bahan pertimbangan atau rujukan ketika konsumen berniat hendak membeli produk. Konsepsi ini erat kaitannya dengan UU PK Pasal 8, Peraturan Pemerintah Republik Indonesia Nomor 69 Tahun 1999 tentang Label dan Iklan Pangan Pasal 44, Kode etik periklanan yang mengatur tata cara dan tata karma periklanan Indonesia. (b) Information markets anad market failures, yaitu informasi pasar yang mengiklankan suatu produk barang dan atau jasa secara berlebihan sehingga konsumen mendapat informasi yang salah. "Markets failures" dalam melakukan pengawasannya bermaknakegagalan pasar dan patut diduga markets failures sengaja dilakukan untuk menarik minat pembeli meskipun tidak tertutup kemungkinan informasiyang salah tersebut disebabkan salah satu pihak antara perusahaan yang mengeluarkan produk atau perusahaan periklanan.

Pemberian informasi yang salah atau menyesatkan adalah suatu larangan yang ditujukan kepada pemilik produk sesuai dengan Pasal 17 UU
PK. (c) Information remedies, yaitu pengendalian, yang diklasifikasikan menjadi 4 kategori umum yaitu (1) Removing restrain on information yaitu suatu usaha usaah untuk melakukan pemantauan sekaligus pengendalian secara terus menerus terhadap informasi produk barang dan jasa yang diterima oleh konsumen. (2) Correcting misleading information yaitu suatu usaha untuk mengklarifikasi klaim (gugatan) yang disebabkan kesalahan dan perilaku buruk dari produsen atau kesalahan periklanan. (3) Encouraging additional information yaitu kecenderungan produsen memeberikan informasi secara berlebihan yang tidak sesuai dengan kondisi dan karakteristik produk yang sebenarnya. (4) Policy Implicationyaitu suatu kondisi dimana hak-hak konsumen untuk mendapatkan informasi yang benar akan semakin tinggi.

Dengan adanya keempat hal yanag berkenaan dengan pemberian informasi kepada konsumen, maka informasi yang harus disampaikan oleh produsen tentang harga (price), jumlah (quantity), mutu (quality), cara penggunaan, efek samping dan keterangan lainnya yang dapat dijadikan produsen sebagai titik tolak atau standar untuk membuat iklan yang baik.Menurut Prof. Hans. W. Micklitz, dalam perlindungan konsumen garis besar dapat ditempuh dengan 2 model kebijkan (Shidarta, 2000). Kebijakan komplementer, suatu kebijakan yang mewajibkan pelaku usaha untuk memberikan informasi yang memadai kepada konsumen (hak atas informasi). Informasi yang harus didapatkan oleh konsumen menurutHoward Bealesadalah informasi tentang manfaat produk, efek samping, tangga; kadaluwarsa, identitas produsen, kehalalan produk, komposisi yang telah teruji tidak membahayakan kesehatan dan kondisi konsumen dikemudian hari. Informasi tersebut daapt disampaikan secara lisan atau tertulis, baik dicantumkan pada label atau melalui media cetak atau elektronik (Miru, 2004).

Keterangan atau informasi yang diberikan oleh produsen akan berdampak signifikan kepada 
produsen baik dampak positif atau dampak negatif. Dampak positif yang terjadi adalah meningkatkan kesetiaan dalam pemakaian produk dan hal tersebut secara otomatis akan meningkatkan keuntungan untuk pelaku usaha, tetapi dampak negatif jika informasi yang diberikan keliru baik sebagian atau seluruhnya maka konsumen dapat menggugat jika terjadi kerugian dna secara otomatis akan merugikan produsen. (2) kebijakan kompensatoris, yaitu kebijakan yang berisi perlindungan terhadap kepentingan ekonomi konsumen (hak atas kesehatan dan keamanan). Hak tersebut dapat dijadikan sebagai titik tolak suatu perlindungan terhadap konsumen karena kesehatan dan keamanan merupakan hal yang sangat dilindungi

Berbagai kasus, konsumen tidak cukup hanya dilindungi dengan kebijakan komplementer (pemberian informasi) tetapi juga harus ditindak lanjuti dengan kebijakan kompensatoris. Meminimalkan resiko dapat dilakukan dengan mencegah beredarnya produk yang tidak lulus pengujian oleh lembaga perizinan pemerintah, hal inidisebut control pra pasar (Shidarta, 2000).

Pengaturan pengaturan kebijakan perlindungan konsumen, terdapat prinsip-prinsip yang harus direalisasikan supaya konsumen mendapatkan perlindungan, diantaranya adalah prinsip kemanfaatan, prinsip keadilan, prinsip keseimbangan, prinsip keamanan dan keselamatan, serta prinsip kepastian hukum.

Perlindungan terhadap konsumen, prinsip yang muncul terkait dengan kedudukan dalam hubungan hukum dengan pelaku usaha adalah Let the buyer beware, prinsip ini disebut caveat emptor. Perkembangannya, asas let the buyer beware ternyata konsumen tidak mendapatkan akses informasi yang menyeluruh terhadap suatu produk. Ketidak mampuan tersebut bisa dikarenakan adanya keterbatasan pengetahuan konsumen tetapi lebih banyak disebabkan karena ketidakterbukaan pelaku usaha terhadap produk yang ditawarkan.

Dengan adanya UU Perlindungan konsumen, kecenderungan caveat emptor yang mengharuskan konsumen harus hati-hati dalam menggunakan produk, hal tersebut dapat diarahkan sebaliknya menuju kepada caveat venditor, dimana pelaku usaha yang harus berhati-hati dalam memberikan informasi atas produk yang di iklankan. The duo care theory, asas ini menyatakan bahwa pelaku usaha mempunyai kewajiban untuk berhati-hati dalam memasarkan produk baik barang atau jasa, jika ditafsirkan secara a contrario maka jika konsumen atau pihak yang dirugikan mempermasalahkan pelaku usaha atas kerugian maka pihak yang dirugikan harus terlebih dahulu dapat membuktikan bahwa pelaku usah tersebut melanggar aturan atau tidak. The privity of contract, asas ini menyatakan pelaku usaha berkewajiban untuk melindungi konsumen tetapi hal tersebut baru akan dilaksanakan jika terjadi hubungan hukum atau hubungan kontraktul sehingga pelaku usaha tidak dapat disalahkan jika terjadi kerugian diluar segala sesuatu diluar yang diperjanjikan artinya konsumen bisa menggugat berdasarkan wanprestasi (contractual liability).

Perkembangan perlindungan terhadap konsumen, secara yuridis sering dinyatakan bahwa antara pelaku usaha dan konsumen mempunyai kedudukan yang sama akan tetapi fakta yang terjadi konsumen tetap menjadi pihak yang selalu mengikuti aturan pelaku usaha, seperti banyak terjadi dalam dunia periklanan dimana pelaku usaha hanya memberikan informasi tentang keunggulan produk dan jarang sekali memberikan informasi tentang kelemahan produk sehingga hal tersebut berimbas jika dikemudian hari terdapat kerugian yang diderita oleh konsumen maka konsumen sendiri yang akan menanggung akibatnya.

\section{Tanggung Jawab Pemegang Iklan (Pengiklan), Perusahaan Periklanan (Advertising) dan Media Periklanan.}

Prinsip pertanggung jawaban merupakan perihal yang sangat penting dalam hukum perlindungan konsumen. dalam kasus tentang pelanggaran hak konsumen yang mengalami kerugian 
baik secara ekonomi maupun secara psikologi, diperlukan suatu kehati-hatian dalam menganalisis siapa yang harus bertanggung jawab dan seberapa jauh tanggung jawab yang dapat dibebankan kepada pihak-pihak terkait dengan pelanggaran peraturan.

Prinsipnya dalam setiap transaksi yang dilakukan oleh konsumen dan produsen secara ekonomis pihak konsumen yang sering dirugikan karena pada dasarnya dalam menggunakan produk, pihak konsumen banyak bergantung pada informasi atau iklan yang sampai pada konsumen.UU PK tidak memberikan rumusan yang jelas dan tegas tentang definisi jenis barang yang secara hukum dapat dipertanggung jawabkan dan sampai seberapa jauh pertanggungjawaban atas barang tertentu dapat dikenakan bagi pelaku usaha tertentu atas hubungan hukumnya dengan konsumen.

Secara umum prinsip pertanggung jawaban dalam hukum dapat dapat dibedakan sebagai berikut: (1) Prinsip tanggung jawab berdasarkan unsur kesalahan (liability based on fault)yakni prinsip yang menyatakan dimana seseorang akan dimintai pertanggungjawaban secara hukum jika ada unsur kesalahan yang dilakukannya.(2) Prinsip tanggung jawab berdasarkan praduga untuk selalu bertanggungjawab (presumption of liability principle), prinsip ini menyatakan bahwa tergugat selalu dianggap bertanggung jawab sampai tergugat dapat membuktikan bahwa dirinya tidak bersalah. (3) prinsip tanggungbjawab berdasarkan praduga tidak bersalah(presumption of nonliability), prinsip ini menyatakan bahwaseseorang dinyatakan untuk tidak selalu membuktikan bahwa dirinya tidak bersalah. (4) Prinsip tanggung jawab mutlak (Strict liability), prinsip ini menyatakan bahwa seseorang harus bertanggung secara penuh atas kesalahan yang dibuat.(5) Prinsip tanggung jawab berdasarkan pembatasan (limitation of liability), prinsip ni sangat disenangi oleh pelaku usaha untuk mencantumkan klasula eksenorasi dalam perjanjian standar yang dibuatnya. UUPK seharusnya pelaku usaha tidak boleh secara sepihak menentukan klausula yang merugikan konsumen, termasuk membatasi maksimalisasi tanggung jawabnya. Jika ada pembatasan, mutlak harus berdasarkan pada peraturan perundang-undangan.

Dua prinsip penting dalam Undang Undang Perlindungan Konsumen yang diakomodasi adalah Tanggung jawab produk dan Tanggung jawab professional (Shidarta, 2000). Tanggung jawab produkmengacu pada tanggung jawab produsen atas produk yang dibawanya sampai pada peredaran yang menimbulkan kerugian karena cacat yang melekat pada produk. Tanggung jawab ini bersifat bersifat kontraktual atau berdasarkan pada UU yang gugatannya berdasarkan hal tentang perbuatan melawan hukum.

Dasar gugatan untuk tanggungjawab produk dapat dilakukan adanya (Shidarata, 2000): landasan pelanggaran jaminan (breache of warranty) dan kelalaian (negligence). UUPK ketentuan yang mengisyaratkan tentang tanggung jawab produk diatur dalam Pasal 7 sampai Pasal 11 UU PK.Tanggung jawab Profesional,berkaitan dengan adanya hubungan dengan jasa.

Tanggung jawab atas pelaku usaha atas kerugian konsumen yang diatur dalam UUPK diatur dalam satu bab tersurat dalam pasal 19 samapi pada Pasal 28 UU PK yang dipilah dalam beberapa bagian yaitu 7 bagian pasal mengatur tanggungjawab pelaku usaha, 2 pasal mengatur pembuktian dan 1 pasal mengatur penyelesaian sengketa dalam hal pelaku usaha tidak memenuhi kewajibannya untuk memberikan ganti kerugian kepada konsumen.

\section{Penerapan Sanksi terhadap Pelanggaran Peraturan Perikalanan}

Penerapan sanksi atas pelanggaran yang dilakukan oleh pelaku usaha, ditentukan dalam Bab XIII dari Pasal 60, 61, 62, dan 63 UU PK dimana sanksi yang diberikan terdiri dari: (1) Sanksi Administratif, dalam ketentuan Pasal 60 Ayat 2 jo 
Pasal 60 Ayat 1 UUPK, sanksi administratif dijatuhkan oleh Badan Penyelesaian Sengkets Konsumen BPSK berupa penetapn ganti rugi sampai setinggi tingginya Rp. 200.000.000,- ditetapkan terhadap pelaku usaha yang melakukan pelanggaran: (a) tidak dilaksananakannya pemberian ganti rugi oleh pelaku usha dalam bentuk pengembalian uang atau penggantian barang atau jasa yang sejenis maupun perawatan kesehatan atau pemberian sanksi atas kerugian yang diderita oleh konsumen. (b) terjadinya kerugian sebagai akibat dari kegiatan produksi iklan yang dilakukan oleh pelaku usaha periklanan.

(2) Sanksi Pidana Pokok,adalah sanksi yang yang dapat dikenakan dan dijatuhkan oleh pengadilan atau tuntutan jaksa umum terhadap pelanggaran yang dilakukan oleh pelaku usaha. Rumusan Pasal 62 UUPK menentukan bahwa pelaku usaha dan atau pengurusnya yang melakukan pelanggaran terhadap ketentuan Pasal 8UU PK tentang barang atau jasa yang tidak memenuhi standar yang ditetapkan, Pasal 9\& Pasal 10 UU PK tentang informasi yang tidak benar, Pasal 11 tentang penjualan secara obral atau lelang, Pasal 12 tentang penawaran dengan tarif khusus, Pasal 13(2) UU PK tentang penawaran obat-obatan dan hal-hal yang berhubungan dengan kesehatan, Pasal 15UU PK tentang penawaran barang secara fisik, Pasal 16 UU PK tentang penawaran melalui pesanan, Pasal 17 (2) UU PK tentang peredaran iklan yang dilarang, Pasal 18UU PK tentang pencantuman klausula baku.

(3) Sanksi Pidana tambahan,ketentuan pidana tambahan diatur dalam Pasal 63 UUPK dapat dijatuhkan berdasarkan ketentuan Pasal 62 UUPK, dengan sanksipidana tambahan yang dijatuhkan berupa: perampasan barng-barang tertentu; pengumuman keputusan hakim pembayaran ganti rugi perintah penghentian kegiatan tertentu yang menyebabkan timbulnyakerugian konsumen; kewajiban penarikan barang dari peredaran; dan pencabutan ijin usaha.

\section{Penyelesaian Sengketa Konsumen}

Sengketa konsumen adalah sengketa yang berkenaan dengan pelanggaran atas hak-hak konsumen, yang dapat diselesikan melalui beberapa tahapan: penyeleseian melalui peradilan, berdasarkan Pasal 45 Ayat 1 UUPK yang menyatakan bahwa, setiap konsumen yang dirugikan dapat menggugat pelaku usaha melalui lembaga yang bertugas menyeleseikan sengketa antara konsumen dan pelaku usaha atau melalui peradilan yang berada dilingkungan peradilan umum".

Kasus perdata di Pengadilan Negeri, pihak konsumen yang diberi hak untuk mengajukan gugatan menurut Pasal 46 UUPK yaitu: seorang konsumen yang dirugikan atau ahli waris yang bersangkutan; sekelompok konsumen yang mempunyai kepentingan yang sama; lembaga perlindungan konsumen swadaya masyarakat yang memenuhi syarat yaitu berbentuk badan hukum atau yayasan yang anggaran dasarnya menyebutkan dengan tegas bahwa tujuan didirikan organisasi itu adalah untuk kepentingan perlindungan konsumen dan melaksanakan kegiatan sesuai dengan anggaran dasarnya.; dam pemerintah atau instansi yang terkait jika barang atau jasa yang dikonsumsi atau dimanfaatkan mengakibatkan kerugian materi yang besar dan atau menyebabkan korban yang tidak sedikit.

Penyeleseian diluar pengadilan,untuk mengatasi keberlikuan proses pengadilan, UUPK memberi jalan alternatif dengan menyediakan penyeleseian diluar pengadilan. Pasal 45 Ayat 4 disebutkan, "Jika telah dipilih upaya penyeleseian sengketa konsumen diluar pengadilan, gugatan melalui pengadilan hanya dapat ditempuh jika upaya itu dinyatakan tidak berhasil oleh salah satu pihak atau oleh pihak yang bersengketa", hal ini mengisyaratkan bahwa penyelesaian di Pengadilan tetap dibuka setelah para pihak gagal menyelesaikan sengketa diluar pengadilan dengan cara Konsiliasi, mediasi atau arbitrase. 


\author{
Jurnal Cakrawala Hukum \\ Vol.8, No.1 Juni 2017: 64-74
}

\section{Simpulan}

Meningkatnya arus globalisasi sangat berdampak pada arus perdagangan dan kreatifitas manusia untuk memunculkan semua hal baru yang belum pernah ada,salah satu kreatifitas yang muncul terkait dengan suatu produk adalah pemasaran produk dengan memberikan informasidengan bahasa, tulisan, dan gambar yang menarik yang disebut iklan dalam Undang-Undang Perlindungan Konsumen. desain iklan yang mengunggulkan produk tertentu menjadi salah satu pemicu konsumen dalam menggunakan produk tanpa diteliti terlebih jauh kebenaran iklan tersebut. Oleh karena itu perlindungan konsumen terkait dengan iklan yang menjadi hal yang esensi dalam penerapan UndangUndnag Perlindungan Konsumen.

Adanya Pasal 8 Undang-Undnag Perlindungan Konsumen, kode etik periklanan dibuat supaya dapat digunakan oleh pelaku usaha untuk membuat iklan atas produk yang akan dipasarkan, tetapi meskipun sudah terdapat peraturan yang memberi batasan kepada pelaku usaha dalam membuat sebuah iklan, sampai saat ini masih sangat banyak iklan yang tidak sesuai dengan batasan yang diberikan oleh peraturan yang ada.

Pelanggaran isi iklan yang tidak sesuai dengan peraturan perundangan-undangan atau kode etik tidak banyak tersentuh sampai ke wilayah pengadilan, banyak pelanggaran yang disadari oleh konsumen tetapi lebih banyak konsumen yang enggan dalam menyelesaikan hal tersebut ke wilayah pengadilan. Rumitnya proses yang di wilayah pengadilan dan keengganan konsumen meyelesaikan pelanggaran ke wilayah luar pengailan membuat iklan yang tidak sesuai dengan UUPK dankode etik periklanan menjadi terbiasa dengan kondisi tersebut.

\section{DAFTAR PUSTAKA}

Husni, Syawali \& Neni Sri Imaniyati. 2000. Hukum Perlindungan Konsumen. Mandar Maju. Bandung. Jefkins, Frank. 1994. Periklanan. Erlangga. Surabaya.
KKPI Nomor 9 Tahun 2004 tentang Pedoman Perilaku Penyiaran dan Standar Program Penyiaran Indonesia. Jakarta.

Nasution, Az. 1995.Konsumen dan Hukum (Tinjauan Sosial, Ekonomi dan Hukum pada Perlindungan Konsumen Indonesia). Sinar Harapan. Jakarta.

Peraturan Pemerintah Republik IndonesiaNomor 11 Tahun 2005 tentang Penyelenggaraan Penyiaran Lembaga Penyiaran Publik. Jakarta.

Peraturan Pemerintah Republik IndonesiaNomor 13 Tahun 2005 tentang Lembaga Penyiaran Publik Televisi Republik Indonesia. Jakarta.

Rampen, Felicia Lidya. 2013. Penggunaan Sanksi Pidana Terhadap Pelanggaran Periklanan Menurut Undang-Undang Perlindungan Konsumen. Lex et Societatis. Vol. I. No.2. 116-124.

Shidarta. 2000.Hukum Perlindungan Konsumen Indonesiaa. Garsindo. Jakarta.

Shofi, Yusuf. 2003. Penyelesaian Sengketa Konsumen. Citra adhitya Bakti. Bandung.

Simatupang,Taufik, H. 2004.Aspek Hukum Periklanan dalam Perspektif Perlindungan Konsumen. Citra Aditya Bakti. Bandung.

Umboh, Harry Richard. 2014. Proses Penyelesaian Pelanggaran Dalam Kegiatan Penyiaran Iklan Niaga. Jurnal Lex Crimen. Vol. III. No. 1. 79-88.

Undang-UndangRepublik Indonesia Nomor 32 Tahun 2002 tentang Penyiaran. Jakarta.

Undang-UndangRepublik Indonesia Nomor 40 Tahun 1999 tentang Pers. Jakarta.

Undang-UndangRepublik Indonesia Nomor 8 Tahun 1999 tentang Perlindungan Konsumen. Jakarta.

\section{How to Cite:}

Laila, Khotbatul. 2017. Perlindungan Hukum Terhadap Konsumen Atas Iklan yang Melanggar Tata Cara Periklanan. Jurnal Cakrawala Hukum. 8 (1): 64-74. 